\title{
Cervical Cancer Registered in Two Developed Regions from Brazil: Upper Limit of Reachable Results from Opportunistic Screening
}

\section{Câncer de colo de útero registrado em duas regiões desenvolvidas do Brasil: limite superior de resultados alcançáveis a partir do rastreamento oportunístico}

Julio Cesar Teixeira ${ }^{1}$ Carlos Afonso Maestri ${ }^{2}$ Helymar da Costa Machado ${ }^{1}$ Luiz Carlos Zeferino ${ }^{1}$ Newton Sérgio de Carvalho 3

${ }^{1}$ Faculdade de Ciências Médicas, Universidade Estadual de Campinas, Campinas, São Paulo, Brazil

Address for correspondence Julio Cesar Teixeira, PhD, MD, Faculdade

2 Service of Lower Genital Tract Pathology, Hospital Erasto Gaertner, de Ciências Médicas, Universidade Estadual de Campinas, Rua Alexander Fleming, 101, 13083-881, Campinas, SP, Brazil

Curitiba, Paraná, Brazil

${ }^{3}$ Faculdade de Ciências Médicas, Universidade Federal do Paraná, (e-mail: juliotex@fcm.unicamp.br; juliotex@uol.com.br).

Curitiba, Paraná, Brazil

Rev Bras Ginecol Obstet 2018;40:347-353.

\begin{abstract}
Keywords

- cervical cancer

- cervical intraepithelial neoplasia

- preventive medicine

- public health

- epidemiology

Objective The aim of this study was to assess the time trends and pattern of cervical cancer diagnosed in the period from 2001 to 2012 by means of an opportunistic screening program from two developed regions in Brazil.

Methods An observational study analyzing 3,364 cancer records $(n=1,646$ from Campinas and $n=1,718$ from Curitiba region) available in hospital-based cancer registries was done. An additional 1,836 records of CIN3/AIS from the region of Campinas was analyzed. The statistical analysis assessed the pooled data and the data by region considering the year of diagnosis, age-group, cancer stage, and histologic type. The Cochran-Armitage trend test was applied and $p$-values $<0.05$ were considered significant.

Results The total annual cervical cancer registered from 2001 to 2012 showed a slight drop (273-244), with an age average of $49.5 \mathrm{y}, 13$ years over the average for CIN3/AIS (36.8 y). A total of $20.6 \%$ of the diagnoses ( $1.6 \%$ under $25 \mathrm{y}$ ) were done out of the official screening age-range. The biennial rate of diagnoses by age group for the region of Campinas showed an increase trend for the age groups under 25 y $(p=0.007)$ and 25 to 44 y $(p=0.003)$. Stage III was the most recorded for both regions, with an annual average of $43 \%$, without any trend modification. There was an increasing trend for stage I diagnoses in the region of Campinas $(p=0.033)$. The proportion of glandular histologic types registered had an increased trend over time $(p=0.002)$, higher for the region of Campinas (21.1\% versus $12.5 \%$ for the region of Curitiba).
\end{abstract}

received July 27,2017 accepted April 16, 2018 published online June 20, 2018
DOI https://doi.org/ 10.1055/s-0038-1660841. ISSN 0100-7203.
Copyright $(2018$ by Thieme Revinter

Publicações Ltda, Rio de Janeiro, Brazil
License terms

(c) $(1) \$$ 


\section{Resumo}

\author{
Palavras-chave \\ - câncer de colo de \\ útero \\ - neoplasia \\ intraepitelial cervical \\ - medicina preventiva \\ - saúde pública \\ - epidemiologia
}

Conclusion The number, pattern and trends of cervical cancer cases registered had mild and slow modifications and reflect the limited effectivity of the opportunistic screening program, even in developed places.

Objetivo Avaliar as tendências temporais e padrão de diagnóstico de câncer de colo de útero (CCU) através de programa de rastreamento oportunístico em duas regiões brasileiras desenvolvidas, no período de 2001 a 2012.

Métodos Estudo observacional com 3.364 registros de câncer ( $n=1.646$ da região de Campinas e $n=1.718$ da região de Curitiba) obtidos de sistemas de registro hospitalar de câncer. Para a região de Campinas foram analisados 1.836 registros adicionais de CIN3/AIS. A análise estatística avaliou os dados agrupados e por região considerando o ano de diagnóstico, grupo etário, estágio de câncer e tipo histológico, e utilizou o teste de tendência Cochran-Armitage com valor $p<0,05$.

Resultados O total anual de CCU registrado no período de 2001 a 2012 apresentou uma ligeira queda (273 para 244), com idade média de 49,5 anos, 13 a mais que a idade média (36,8 anos) para CIN3/AIS. O total de diagnósticos realizados fora da faixa etária oficial de rastreamento foi $20,6 \%$ (1,6\% abaixo de 25 anos). Houve uma tendência de aumento de casos nas faixas etárias inferior a 25 anos $(p=0,007)$ e de 25 a 44 anos $(p=0,003)$ para a região de Campinas. Ambas as regiões apresentaram maior proporção diagnósticos de câncer em estágio III (43\% em média), sem modificação de tendência. Houve tendência crescente para diagnóstico em estágio I na região de Campinas $(p=0,033)$ e da proporção de tipos histológicos glandulares em ambas regiões ( $p=0,002), 21,1 \%$ para a região de Campinas e 12,5\% para Curitiba.

Conclusão O número, o padrão e as tendências dos casos registrados de câncer de colo de útero apresentaram modificações pequenas e lentas ao longo do tempo, reflexo da efetividade limitada do programa de rastreio oportunista, mesmo em locais desenvolvidos.

\section{Introduction}

Cervical cancer (CC) is a preventable neoplasia with known etiology and precursor lesions of slow evolution, able to be screened. ${ }^{1}$ Screening in Brazil is based on cytology for women from 25 to 64 years old, and is performed every 3 years, after two consecutive negative annual tests, and is currently available for the entire country with different degrees of access, depending on the region. ${ }^{2}$ The Brazilian screening program is considered opportunistic, with no control over the screened population, resulting in limited impact on the incidence and mortality from this type of cancer. ${ }^{3}$ The official estimate is 16,340 new cases in 2016 , one of the most prevalent types of cancer, but with great regional variability. ${ }^{4,5}$

Currently, an important amount of information about cancer available for the Brazilian population comes from the Hospital-Based Cancer Registries (HCRs) system, which started working in the late 1990 s. $^{6}$ This information is considered consistent and being used by the Brazilian National Cancer Institute (INCA, in the Portuguese acronym) to audit and plan health care assistance. ${ }^{6}$

The cities of Campinas (São Paulo State [SP]) and Curitiba (Paraná State [PR]), located respectively in the Southeast and South of Brazil, administer two major metropolitan areas, with high human development indexes (HDIs) of 0.805 and 0.823 , respectively. ${ }^{7}$ The region of Campinas has 82 cities with 5.5 million people, and the region of Curitiba has 95 cities with a population of 5.1 million..$^{8,9}$ Both regions represent around $5 \%$ of the Brazilian population. Both main cities keep their cancer centers in hospitals where treatment is available and have had HCRs since 2000. Regions covered for both main cities have a well-developed network available for primary health care as part of the Brazilian Public Health System (SUS, in the Portuguese acronym), in which cytological screening of CC is available. Routinely, cases with suspicion of high-grade intraepithelial lesion or CC are referred to specialized centers, often regional.

Therefore, the aim of this study was to assess the time trends and pattern of CC diagnosed in the period from 2001 to 2012 at the comprehensive hospitals for cancer management of the regions of Campinas (SP) and Curitiba (PR), and evaluate the changes related to opportunistic screening in a scenario of socioeconomic development.

\section{Methods}

This was an observational study with information collected from HCRs of SUS Regional Hospitals related to CC management 
between January 2001 and December 2012. Hospitals from cities of Campinas (SP) and Curitiba (PR) were considered.

We considered all records with the $\mathrm{C} 53$ disease classification code (CC) in the 10th revision of the International Classification of Diseases (ICD-10) and patients aged $\geq 15$ years, totalizing 3,875 subjects. Histological types considered were squamous cell carcinoma (SCC), adenocarcinoma (AC) and adenosquamous carcinoma (ASC), in accordance with the International Classification of Diseases for Oncology (ICD-O). ${ }^{10,11}$ The cases excluded were uncommon histological types less detectable by screening or secondary cancers ( $n=58)$, and all cases arising from cities outside the official regions coverage for Campinas and Curitiba $(n=453)^{8,9}$

Therefore, 3,364 records were analyzed, 1,646 from Campinas and 1,718 from Curitiba. Additionally, we evaluated a series of 1,836 cervical intraepithelial neoplasia grade 3 (CIN3) or adenocarcinoma in situ (AIS) by age group, registered at same period, from regional hospital of Campinas region, as a reference to compare with cancer data.

\section{Statistical Analysis}

The longitudinal pattern rates of the diagnoses registered between 2001 and 2012 was analyzed according to period (biennial), age-group (up to $25 \mathrm{y}, 25-64 \mathrm{y}$ - the age range of official cytological screening program in Brazil, and more than $64 \mathrm{y}$ ), International Federation of Gynecology and Obstetrics (FIGO, in the Portuguese acronym) stage, and histologic type (World Health Organization [WHO] classification) ${ }^{2,11,12}$ The Cochran-Armitage trend test was applied by region of care, and by aggregate data, using the SAS 9.2 program (SAS Institute Inc., Cary, NC, USA), and $p$ values $<0.05$ were considered significant. ${ }^{13}$

This study followed the regulatory standards of the National Health Council of Brazil and was approved by the local ethics committee of each institution (CAAE 38524914.1.0000.5404).

\section{Results}

The CC registries analyzed by region had similar proportions for almost all variables (year, age group, cancer stage, and histology), with some punctual differences observed in cancer stage and histological type ( - Table $\mathbf{1}$ ).

The age group distribution of cancer showed a similar pattern in both regions, with a peak around 45 to $49 \mathrm{y}$. The age average for the total aggregate was $49.5 \mathrm{y}(15-97), 13$ years later than the $36.8 \mathrm{y}$ age average for CIN3 or AIS (distribution peak around 30 years) available for the region of Campinas.

The total annual cases of cancer registered and the breakdown by region showed a slight drop during the period studied, from 273 cases in 2001 to 244 cases in 2012 (Years 2001-2012: Campinas 141-133 cases, Curitiba 132-111 cases). For the region of Campinas, the number of cases of CIN3 and AIS registered yearly over time was compared with the cancer registries and showed a trend towards increase (121 cases in 2001 and 177 cases in 2012, $p<0.001$ ) (-Fig. 1, dotted line).
Table 1 Distribution of cervical cancer cases registered by region according to some parameters

\begin{tabular}{|c|c|c|c|}
\hline \multirow[t]{2}{*}{ Parameter } & Campinas & Curitiba & $\begin{array}{l}\text { Total } \\
\text { aggregate }\end{array}$ \\
\hline & n (\%) & n (\%) & $\mathrm{n}(\%)$ \\
\hline \multicolumn{4}{|l|}{ Year } \\
\hline 2001-2002 & 319 (19.4) & $289(16.8)$ & $608(18.1)$ \\
\hline $2003-2004$ & $264(16.0)$ & $316(18.4)$ & $580(17.2)$ \\
\hline 2005-2006 & $271(16.5)$ & $292(17.0)$ & $563(16.7)$ \\
\hline 2007-2008 & $292(17.7)$ & $266(15.5)$ & $558(16.6)$ \\
\hline $2009-2010$ & $240(14.6)$ & $285(16.6)$ & $525(15.6)$ \\
\hline 2011-2012 & $260(15.8)$ & $270(15.7)$ & $530(15.8)$ \\
\hline \multicolumn{4}{|l|}{ Age group (year) ${ }^{a}$} \\
\hline$<25$ & $25(1.5)$ & $29(1.7)$ & $54(1.6)$ \\
\hline $25-44$ & $537(32.6)$ & $679(39.5)$ & $1,216(36.2)$ \\
\hline $45-64$ & $712(43.3)$ & $743(43.3)$ & $1,455(43.3)$ \\
\hline$>64$ & $372(22.6)$ & $266(15.5)$ & $638(19.0)$ \\
\hline \multicolumn{4}{|l|}{ Stage (FIGO) } \\
\hline I & $585(36.1)$ & $415(31.6)$ & $1,000(34.1)$ \\
\hline II & $171(10.5)$ & $308(23.5)$ & $479(16.3)$ \\
\hline III & $751(46.3)$ & $521(39.7)$ & $1,272(43.3)$ \\
\hline IV & $115(7.1)$ & $69(5.3)$ & $184(6.3)$ \\
\hline $\begin{array}{l}\text { Missing } \\
\text { information }\end{array}$ & 24 & 405 & 429 \\
\hline \multicolumn{4}{|l|}{ Histologic type } \\
\hline Squamous cell & $\begin{array}{l}1,299 \\
(78.9)\end{array}$ & $\begin{array}{l}1,502 \\
(87.4)\end{array}$ & $2,801(83.3)$ \\
\hline Adenocarcinoma & $277(16.8)$ & $198(11.5)$ & $475(14.1)$ \\
\hline Adenosquamous & $70(4.3)$ & $18(1.0)$ & $88(2.6)$ \\
\hline Total & $\begin{array}{l}1,646 \\
(100.0)\end{array}$ & $\begin{array}{l}1,718 \\
(100.0)\end{array}$ & $\begin{array}{l}3,364 \\
(100.0)\end{array}$ \\
\hline
\end{tabular}

Abbreviation: FIGO, International Federation of Gynecology and Obstetrics. ${ }^{\mathrm{a}} 1$ case missed for Curitiba region.

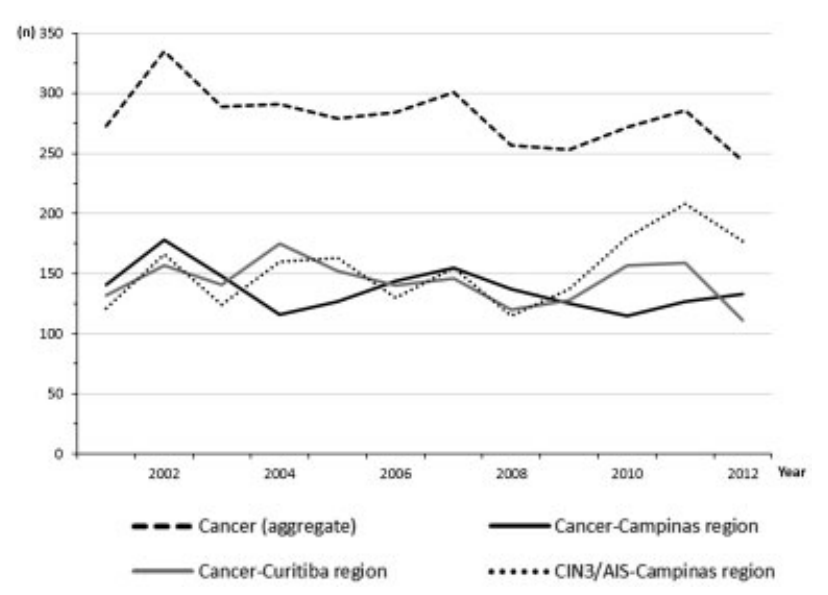

Fig. 1 Number of women with cervical cancer and cervical intraepithelial neoplasia grade 3 (CIN3) or adenocarcinoma in situ (AIS) registered yearly, total (aggregate) and by region. 
The trend in detection of cancer by age group in the region of Campinas showed an increase in the number of cases at ages under 25 years $(n=2$ or $0.6 \%$ in $2001-2002$ to $n=8$ or $3.1 \%$ in $2011-2012, p=0.007)$ and 25 to 44 years $(n=91$ or $28.5 \%$ to $n=103$ or $39.6 \%, p=0.003$ ). There was a decreasing trend for diagnoses in the age group 45 to 64 years (from $n=143$, or $44.8 \%$, to $n=96$, or $36.9 \%, p=0.008)$ and maintained trend in age 65 years or more $(n=83$, or $26.0 \%$, to $n=53$, or $20.4 \%, p=0.306$ ) (-Fig. 2A-B). While the same pattern was observed for the aggregate data, the region of Curitiba showed no significant changes in trend during the period studied ( - Fig. 2 C).

There was $13 \%$ rate of missing information about cancer clinic stage for the region of Curitiba. Stage III was the most recorded for both regions, without any modification trend over the period evaluated, with an annual average of $43 \%$

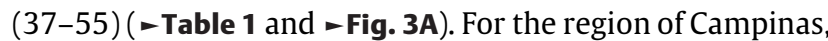
a significant increasing trend of proportion for stage $I$ at diagnosis was observed, with $32 \%(n=99)$ in 2001 to 2002 and $40 \%(n=103)$ in 2011 to $2012(p=0.033)$ (-Fig. 3A), and the absolute numbers for stages II-IV were $n=208$ in 2001 to 2002 and $n=157$ in 2011 to 2012.

The histological types distribution over time showed a similar pattern for both regions, with significant trend to increase diagnoses of glandular cancer (adenocarcinoma $[A C]$ or atypical squamous cell [ASC]) and decreasing squamous cell carcinoma (SCC). The proportion of glandular cancer changed from 15.0 (in 2001-2002) to $21.1 \%$ (for 2011-2012) $(p=0.002)$, more evident in the region of Campinas (from 21.6\%-26.2\%) than in Curitiba (from 7.6\%16.3\%) (-Fig. 3B).

\section{Discussion}

The annual rate of diagnoses of CC registered in the referral hospitals from two developed Brazilian regions showed a slight drop in the period from 2001 to 2012. Most cases of cancer recorded were in the age group 45 to 64 years and at stage III. There were increasing trends in proportion of diagnoses below 45 years and cancer with glandular histology. In the region of Campinas, we observed an increasing trend of cancer diagnosed in stage I compared with stages II to IV.

Screening programs with periodic cytology aim to detect precursor lesions and reduce the incidence of cancer and mortality rates. After their implementation and with maintenance over time, the number of cancer cases may decrease gradually, depending on the level of organization. The initial effect expected is diagnosis in advance, with detection of neoplasia in younger women and at early stages, and then, increasing diagnosis of CIN3. After this, a greater impact on histological type SCC compared with AC should be observed. ${ }^{14,15}$

In this study, there was a small and slow decline in the number of cancer cases registered, although it was consistent and in both regions. This pattern is similar to previously reported results of cytological screening and mortality in Brazil. 5,16

Another factor related to the positive impact of screening on CC observed in these regions is the opposite pattern of CIN3 or AIS records, available for the region of Campinas, with significant upward trend in diagnostics, one of the main goals of screening programs. ${ }^{14,15}$

The region of Curitiba showed no significant changes by age group, and the changes observed at total aggregate data

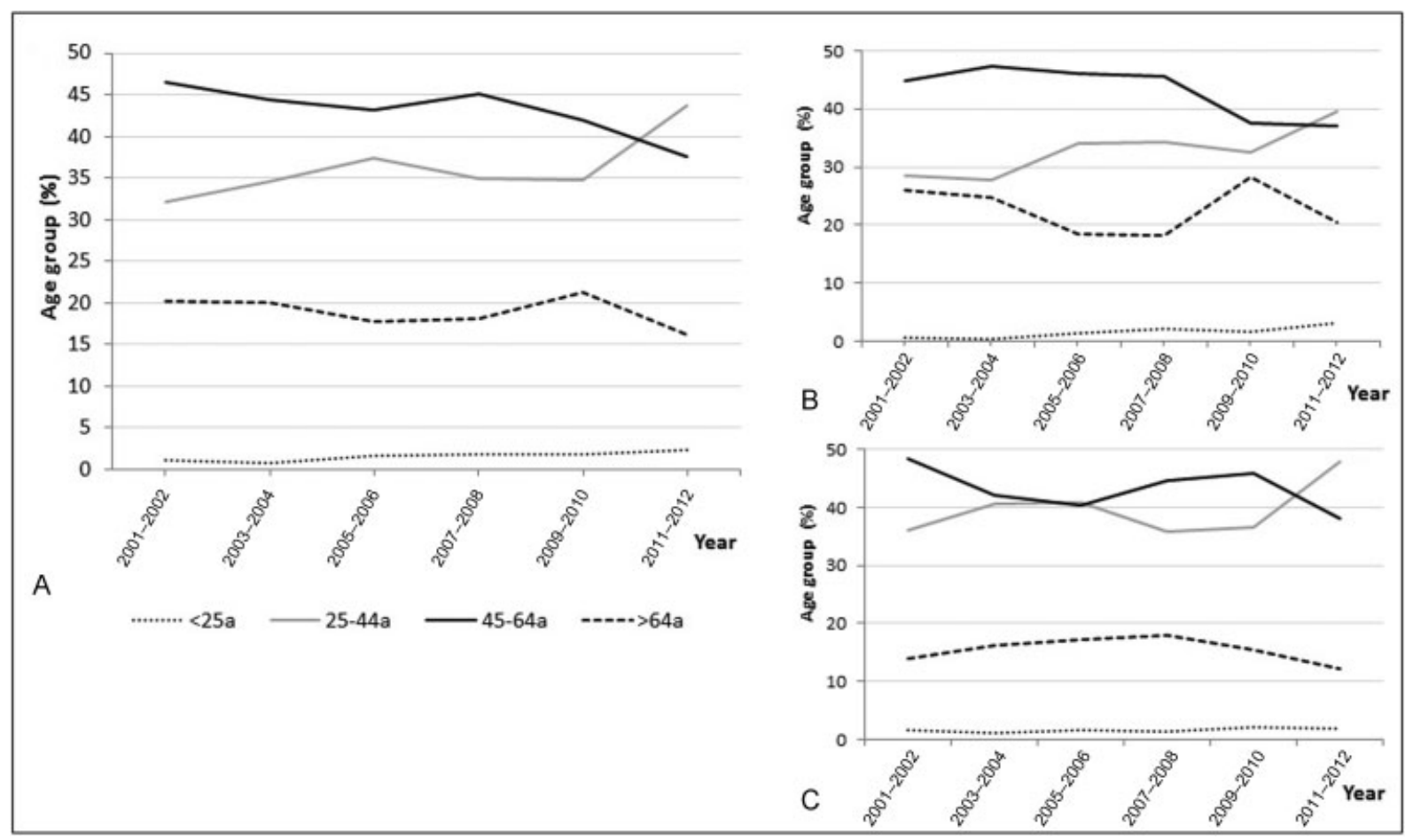

Fig. 2 Biennial percentage distribution of cervical cancer registered between 2001 and 2012, by age-group and region (A = Total aggregate; $\mathrm{B}=$ Campinas; $\mathrm{C}=$ Curitiba). 

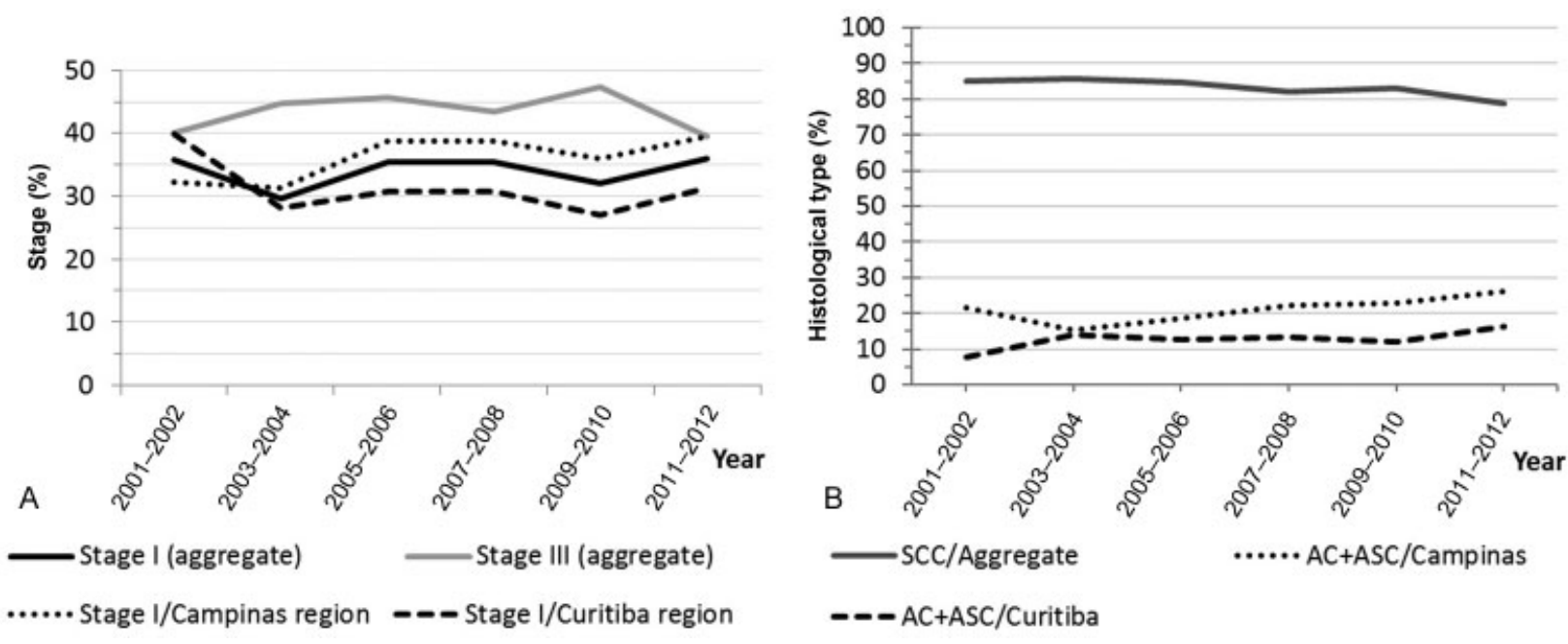

Fig. 3 Biennial percentage distribution of cervical cancer registered in the period from 2001 to 2012 by (A) cancer stage according to the International Federation of Gynecology and Obstetrics (FIGO, in the Portuguese acronym), (B) histological type (SCC: Squamous cell carcinoma; AC: adenocarcinoma; ASC: adenosquamous carcinoma) and region.

were due to changes from the region of Campinas. The region of Campinas showed a significant trend for increased diagnoses in those patients younger than 45 years and decreased cases between 46 and 64 years, demonstrating a possible anticipation of diagnosis. On the other hand, both regions exhibited 19 to $22 \%$ of cases of cancer registered after 64 years of age, which is the upper age limit for the Brazilian Screening Program and with no trend changes, maybe indicating lower effectivity (or coverage) of the screening program at earlier ages. In general, almost all women who had cervical cancer after 64 years-old had not performed a standard screening before. Brazilian guidelines advise 2 to 3 negative pap tests in the past 10 years to stop the screening.

Comparing both regions, the trend for $\mathrm{CC}$ registered below 25 years observed in Campinas region draws attention. In Brazil, the routine screening begins at age 25 , and a report based on regional data from the state of São Paulo referring to the period from 2000 to 2009 , stated that only $1 \%$ of all CC cases was recorded below 25 years. ${ }^{2}$ Besides, the biennial number of CC cases under 25 years is low, our study indicates that this number tends to increase over time, especially in the region of Campinas. Maybe it reflects the cultural and behavioral characteristics. A published study with Brazilian adolescents and young adult women, including both cities of Campinas and Curitiba, showed a high prevalence of highrisk HPV infection. ${ }^{17}$ Our findings add information for a possible revision in the Brazilian program regarding the age to start the screening, as it has already happened in other countries, such as USA, England, Germany, Denmark and Sweden. ${ }^{18,19}$

Regarding the cancer stage, there was a high percentage of cases in stage III, around $40 \%$ for both regions, a pattern consistent with lack of screening effectivity. ${ }^{20}$ Only the region of Campinas showed an increasing trend for diagnoses in stage I, compatible with a certain anticipation of diagnosis.

Historically, the epidemiology about histological type of CC trend to change overtime as consequence of cervical sampling technique, that are more representative of ectocervix than endocervix, resulting in a greater impact on detection of squamous premalignant lesions compared with glandular neoplasia. ${ }^{14,15}$ Similarly, our results indicate progressive changes for both regions in the proportion of glandular epithelium cancers (AC or ASC) over time. Campinas region that changed glandular histology from 22 to $26 \%$ in the period from 2001 to 2012, a proportion considered high and found in countries after decades of effective screening. ${ }^{14,15}$

Although this study presents some limitations, such as lack of information about tumor stage in $23 \%$ of the cases registered in the region of Curitiba, the information analyzed can be considered as an adequate representation of the women assisted by the SUS. Another point to clarify is the coverage of the SUS assistance and the representativeness of the data evaluated. The regions studied have had an important economic development and up to $50 \%$ of their populations has had access to private health care assistance for some periods. Nevertheless, there are few services out of the SUS to care for women with CC, and the hospitals studied remain as the main reference centers until now. The HCR from each hospital has dedicated professionals and record information from $100 \%$ of the assisted cases, indicating that the data analyzed here have significant power to provide consistent and useful information to support future action. Further studies are essential to confirm our findings.

In summary, both regions exhibited positive changes, some of them remarkable, perhaps as result of the strong commitment to control this cancer observed in the health care system of these regions. Still, the results are modest but encouraging and reflect the lack of organization of these programs. While the Brazilian Ministry of Health states that the country has a national organized screening program and shows numbers of cytology performed annually sufficient to cover $90 \%$ of the target population of the program, the reality is different. There is a high proportion of cytologies performed outside the target age group and at shorter intervals, usually annual intervals, 
resulting in a real coverage not exceeding $30 \%$, as reported by Freitas et al, ${ }^{21}$ for the region of Campinas in 2003. Most of the cytologies performed have no impact on this type of cancer, and this is reflected in the results presented in this study, typical of opportunistic programs.

It should be evident that additional efforts are needed and must be directed to correct what is missing so far: an individual population registration system for preventive health actions that can be fed and checked continuously. After that, the next step would be just the surveillance and effective communication with women who deviate from the planned screening protocol. The positive cases would call for the reassessment of other steps, including quality control of laboratories that perform cytology exams.,22

Based on the Brazilian history in this field, it may take a few decades for an effective action to take place and, unfortunately, thousands of women will succumb to this preventable disease, since the current program is not able to detect most of the cases at curable stage. In the near future, the time will come to screen vaccinated women, and a positive and impactful effect on the incidence of $\mathrm{CC}$ will require an organized program, with individual registries and an adequate quality control of the various steps involved, or conversely, the potential of the vaccination program that Brazil is doing maybe also be put at risk.

Our data exhibited the limitations of an opportunistic screening, notably a stagnation of the impact over time to decrease the number of cancer cases and mortality, while maintaining a high proportion of diagnosis in advanced stages. In this study, there was a maintenance trend for diagnoses in stage III, around $40 \%$ for the 2 regions, confirming the limitation of the local programs, although an increased trend for cancer detection in stage I has been observed in the region of Campinas.

\section{Conclusion}

The cases of CC registered for both regions had mild and slow positive modifications, more evident in the region of Campinas, with an increased number of cases of CIN3 or AIS, trend for more diagnoses in younger patients, those in stage I, and cases of glandular neoplasia. The results observed are modest and can be considered as an indicator of the reachable upper limit of effectiveness expected by an opportunistic screening program. Additional efforts should be directed to organize the program, and further studies are essential to confirm our findings.

\section{Contributions}

Teixeira J. C., Maestri C. A., Machado HC, Zeferino L. C. and Carvalho N. S. contributed with the project and interpretation of data, writing of the article, critical review of the intellectual content and final approval of the version to be published.

\section{Conflicts of Interest}

The authors have no conflicts of interest regarding this manuscript.
Acknowledgements

This work was supported by GlaxoSmithKline Biologicals S.A. [EPI-HPV-047 BOD BR SUPP].

\section{References}

1 Zeferino LC, Derchain SF. Cervical cancer in the developing world. Best Pract Res Clin Obstet Gynaecol 2006;20(03):339-354. Doi: 10.1016/j.bpobgyn.2006.01.018

2 Ministry of Health. Brazilian National Cancer José Alencar Gomes da Silva Institute. [Brazilian Guidelines for the Screening of Cervical Cancer]. $2^{\text {nd }}$ ed. Rio de Janeiro, RJ: INCA; 2016

3 Costa RF, Longatto-Filho A, Pinheiro C, Zeferino LC, Fregnani JH. Historical analysis of the Brazilian cervical cancer screening program from 2006 to 2013: a time for reflection. PLoS One 2015;10(09):e0138945. Doi: 10.1371/journal.pone.0138945

4 Ministry of Health. Brazilian National Cancer José Alencar Gomes da Silva Institute. [Estimate 2016: Incidence of Cancer in Brazil]. Rio de Janeiro, RJ: INCA; 2015http://santacasadermatoazulay.com.br/wpcontent/uploads/2017/06/estimativa-2016-v11.pdf. Accessed May 5, 2016

5 Vale DB, Sauvaget C, Muwonge R, et al. Disparities in time trends of cervical cancer mortality rates in Brazil. Cancer Causes Control 2016;27(07):889-896. Doi: 10.1007/s10552-016-0766-x

6 Ministry of Health. Brazilian National Cancer Institute. [Hospital Registry of Cancer - Annual Report: 1994/1998]. http://www1.inca. gov.br/rhc/docs/apresentacao.pdf. Accessed May 5, 2016

7 United Nations Development Programme. Human Development Index (HDI). 2010. http://www.undp.org/content/brazil/pt/home/ idh0.html. Accessed May 5, 2016

8 State Secretary of Health. [State of São Paulo According to Health Departments, 2012]. http://www.saude.sp.gov.br/ses/institucional/ departamentos-regionais-de-saude/regionais-de-saude. Accessed May 5, 2016

9 Secretary of Health. [State of Parana Regional Health]. http://www. saude.pr.gov.br/modules/conteudo/conteudo.php?conteudo=2752. Accessed on May 5, 2016

10 World Health Organization. International Statistical Classification of Diseases and Related Health Problems 10th Revision: ICD-10 version 2015. http://apps.who.int/classifications/icd10/browse/ 2015/en\#/. Accessed May 5, 2016

11 World Health Organization. International Agency for Research on Cancer. International Classification of Diseases for Oncology (ICD-O). $3^{\text {rd }}$ ed. Geneva: WHO; 2013http://codes.iarc.fr/. Accessed May 5, 2016

12 FIGO Committee on Gynecologic Oncology. FIGO staging for carcinoma of the vulva, cervix, and corpus uteri. Int J Gynaecol Obstet 2014;125(02):97-98. Doi: 10.1016/j.ijgo.2014.02.003

13 Boyle P, Parkin DM. Cancer registration: principles and methods. Statistical methods for registries. IARC Sci Publ 1991;95(95):126-158

14 Miller AB, Nazeer S, Fonn S, et al. Report on consensus conference on cervical cancer screening and management. Int J Cancer 2000;86 (03):440-447. Doi: 10.1002/(SICI)1097-0215(20000501)86:3<440: AID-IJC22>3.0.CO;2-A

15 Quinn M, Babb P, Jones J, Allen E. Effect of screening on incidence of and mortality from cancer of cervix in England: evaluation based on routinely collected statistics. BMJ 1999;318(7188):904-908. Doi: 10.1136/bmj.318.7188.904

16 Gonzaga CM, Freitas-Junior R, Barbaresco AA, Martins E, Bernardes BT, Resende AP. Cervical cancer mortality trends in Brazil: 19802009. Cad Saude Publica 2013;29(03):599-608. Doi: 10.1590/S0102$311 \times 2013000700017$

17 Roteli-Martins CM, de Carvalho NS, Naud P, et al. Prevalence of human papillomavirus infection and associated risk factors in young women in Brazil, Canada, and the United States: a multicenter cross-sectional study. Int J Gynecol Pathol 2011;30(02): 173-184. Doi: 10.1097/PGP.0b013e3181f38dfe 
18 Anttila A, Ronco G; Working Group on the Registration and Monitoring of Cervical Cancer Screening Programmes in the European Union; within the European Network for Information on Cancer (EUNICE). Description of the national situation of cervical cancer screening in the member states of the European Union. Eur J Cancer 2009;45(15):2685-2708. Doi: 10.1016/j. ejca.2009.07.017

19 Watson M, Saraiya M, Benard V, et al. Burden of cervical cancer in the United States, 1998-2003. Cancer 2008;113(10, Suppl)2855-2864. Doi: 10.1002/cncr.23756
20 Sankaranarayanan R, Budukh AM, Rajkumar R. Effective screening programmes for cervical cancer in low- and middle-income developing countries. Bull World Health Organ 2001;79(10):954-962

21 Freitas RAP, Carvasan GAF, Morais SS, Zeferino LC. Excessive Pap smears due to opportunistic cervical cancer screening. Eur J Gynaecol Oncol 2008;29(05):479-482

22 Derchain S, Teixeira JC, Zeferino LC. Organized, population-based cervical cancer screening program: it would be a good time for Brazil now. Rev Bras Ginecol Obstet 2016;38(04):161-163. Doi: 10.1055/s-0036-1582399 